\title{
Investment-Cash Flow Sensitivity: A Study of Iranian Listed Companies
}

\author{
Mahdi Salehi ${ }^{1}$, Ali Mohammadi ${ }^{2}$, Parisa Taherzadeh Esfahani ${ }^{3}$ \\ ${ }^{1}$ Ferdowsi University of Mashhad, Faculty of Economics and Business Administration, Azadi Square, Vakilabad Bolvard, \\ Mashhad City, Khorasan Razavi Province, Iran, mahdi.salehi@um.ac.ir (corresponding author) \\ ${ }^{2}$ Department of Accounting, Zanjan Branch, Islamic Azad University, Zanjan, Iran \\ ${ }^{3}$ Department of Accounting, Islamic Azad University, Zanjan Sciences \& Research Branch, Iran
}

\begin{abstract}
The main objective of the current study is to examine the effect of audit report on cash-flow investment sensitivity of 123 listed companies in Tehran Stock Exchange (TSE) during 2006-2010. Regression analysis and synthetic data were used for data analysis. The results showed that receiving modified report has a significant negative effect on cash flow-investment sensitivity. The findings also suggest the significant effect of receiving qualified report and unqualified report with explanatory paragraphs on cash flow-investment sensitivity.
\end{abstract}

Keywords: Auditing, auditor report, cash flow-investment sensitivity, Iran.

\section{Introduction}

The emphasis on capital market imperfections is certainly not a novel idea in empirical studies focusing on the investment behavior of firms in developing countries. As far back as the work of Meyer and Kuh (1957) there has been an awareness of the significance of financing constraints on firm-level business investment. However, since the mid-1960's, most applied work attempted at isolating real firm decisions from purely financial factors. The justification for this approach stemmed from Modigliani and Miller (1958) demonstrating the irrelevance of financial structure and financial policy for real investment decisions, albeit under certain conditions. The central Modigliani-Miller result was that in frictionless capital markets, internal and external sources of capital become perfect substitutes thereby making real firm decisions, such as fixed investment, independent of financial factors such as firm-liquidity, leverage, or dividend policy.

During the last decade, several studies have been done on financial constraints and cash flow-investment sensitivity of firms (Fan and Wong, 2005; Lin, Jiang and $\mathrm{Xu}, 2011)$. Almost all of these studies have underlined the significant effect of financial constraint on cash flowinvestment sensitivity (Myers and Majluf, 1984; Li et al., 2008). Moreover, taking appropriate investment deci- sions and using the cash flows in profitable investment opportunities is possible only under certain conditions one of which is the access to sufficient financial resources (Carreira and Silva, 2010). Financial constraints have different sources. According to the literature, information asymmetry and agency dilemma are the most important factors in the resource allocation process of businesses (Kassimand and Menon, 2003). In fact, with increasing information asymmetry and principal-agent problem, firms will be faced with problems in obtaining necessary financial resources (Wang and Chen, 2003; Lin and Huang, 2011).

One of the mechanisms for reducing information asymmetry and agency dilemma is to audit financial statements (Bottom, et al. 2006; Campello et al., 2010). The theory suggests that a high level of information asymmetry may result in costly or unavailable external financing and overreliance on internal funds. Therefore, the sensitivity is higher for constrained firms (Myers and Majluf, 1984). Audit report is, in effect, verifies the quality of financial statements. Investors put much emphasis on the quality of financial information in their decisionmaking (Beatty et al., 2010). On the other hand, given the effect of financial constraints on cash flow-investment sensitivity and the effect of audit report and quality of financial information on financial constraints (e.g. information asymmetry and agency dilemma) (Guariglia et al., 2011; Bekaert et al., 2012; Barzegar and Salehi,

Received: $17^{\text {th }}$ February 2013; revised: $16^{\text {th }}$ April 2013; accepted $29^{\text {th }}$ April 2013 
2008), the question is whether audit report has any effect on cash flow-investment sensitivity Thus, the present research tries to find whether audit report affects cash flow-investment sensitivity of listed companies in TSE.

\section{A brief history of auditing in Iran}

Accounting in the world has a background of 6000 years and the first accounting documents were discovered 3600 years before Christ's birth. Documents of ancient Iran show that in 500 B.C., all records of public revenues and costs were kept soundly and with remarkable accuracy (Mashayekhi and Mashayekh, 2008). Here we are going to explain brief history of auditing in Iran after Revolution. Islamic Revolution of Iran in 1979 resulted in electing governmental managers for some companies, expropriating companies belonging to a number of capitalists affiliated to the past Shah's Regimen and nationalizing some of the industrial entities. Proprietorship of public economical entities necessitated the formation of institutes to audit the accounts of the national economic or expropriated companies and entities, and formation of audit institutes of National Industries and Planning Organization, Foundation of the Oppressed and Martyr's Foundation was necessitated from 1980 to 1983 . The case of merging the audit bodies of public division was propounded in 1983, and law of founding the audit organization was approved. By approving the statutes of the Audit Organization in 1987, public audit bodies merged and the Audit Organization was established.

In the Certified Statutes and Act of Audit Organization, the responsibilities of Certified Inspector and audit affairs of all agencies and apparatuses, which were under the public proprietorship, were ceded to the Audit Organization.

Furthermore, the Audit Organization was recognized as a specialized and official reference to compile principles, and regulations of accounting and auditing. Hence, for the first time, legal inspection tasks and audit were in practice consolidated, and an organization to audit the financial institutions of public division and an official reference to compile principles and standards of accounting and auditing were ordained (Salehi and Abedini, 2008).

After the Islamic revolution of Iran in 1979, according to a bill ratified by the Revolutionary Council, many enterprises were confiscated or came under direct supervision of Government. To audit and perform statutory examination of these enterprises, three audit firms were established in the public sector, i.e., Nationalized Industries and Plan Organization Audit Firm in1980, Mostazafan Foundation Audit Firm in1981, Shahed Audit Firm in 1983 (Salehi, 2008).

In 1983 an act was ratified by the Parliament, to merge and embody these three audit firms together with Audit Company (established in 1971 to audit government corporations) to establish Audit Organization. Audit Organization's by-laws were also approved by the
Parliament in 1987 and the Organization was established as a legal entity with financial independence, affiliated to the Ministry of Economic Affairs and Finance to follow those audit firms functions and pursue the activities legislated in the Organization's Act and by-laws. Audit Organization's by-laws were revised and approved by the Council of Ministers in 2003 to comply with the Article 4 of the Third Economic, Social and Cultural Development Plan and the Organization's legal status changed to State Owned Limited Company.

The Organization's main objectives are: (i) To provide government with basic needs in the field of auditing and specialized financial services for state owned and government supervised entities; (ii) To set Accounting and Auditing Standards and Professional Ethics in compliance with Islamic Rules as well; and (iii) To conduct research in scientific and practical methods of accounting to enhance accountancy compatible with country's needs. The Board of Governors comprises of Minister of Economic Affairs and Finance as chairman, Head of Management and Planning Organization, Minister of Petroleum, Minister of Industries and Mines and Minister of Commerce. The Board sets policies of the Organization; approves plans, manuals and financial statements of the Organization; and appoints members of the Board of Executives Accounting and Auditing Standards and also the Board of Governors should approve the Organization's Code of Ethics and its disciplinary rules. The Board of Executives comprises of Chairman and Chief Executive Officer of the Organization and four or six expert accountants, all appointed by the Board of Governors. The Board is responsible for planning, organizing, preparing manuals, managing and execution of programs. Each Board member directs and supervises a part of the Organization's activities Exposure drafts of accounting and auditing standards should be reviewed and confirmed by the Board of Executives before submission to the Board of Governors.

High Supervisory Council comprises of three expert accountants appointed by the Board of Governors and is responsible for continuous supervision of the Audit Organization's activities, review of internal control system, statutory examination of the Organization's financial statements and reporting its findings to the Board of Governors and where appropriate to the regulatory bodies (Salehi et al., 2009).

In fulfilling its main function to audit and statutory examination of state owned companies in 2003-04, Audit Organization has audited banks; insurance companies; oil, gas and petrochemical companies; regional water and power corporations; post, telegraph and telephone companies; and steel, tobacco and many other large corporations. Social Security Organization, Mostazafan and Janbazan Foundation, Shahid Foundation, and 15th Khordad Foundation and their affiliated companies are another major group of entities audited by the Organization. Investment companies and other enter- 
prises controlled by banking system are also among those entities audited by the Organization.

\section{Iran stock exchange}

Iran has many characteristics that could potentially turn it into one of the most attractive investment options. Its unique geographical location borders it with significant business partners far and near, so much that many consider it to be a cross-road connecting Middle East to Europe and Asia. Iran has a demand oriented consumer base. Its domestic market is still growing as its seventy million populations is expected to grow in the future. Iran has invested a lot in the training of its youth. The system of public and private universities was expanded, starting from the $1980 \mathrm{~s}$, to meet the need of the Iranian baby boomers that were born during that era. The result of this effort has emerged into a highly educated and motivated work force that could potentially be put to work in various areas of the industry thus expanding the economical horizons.

Iran has also been gifted with plentiful amounts of natural resources. Its vast oil fields located in the south and partly in the north region of the country are a huge source of income. New fields are actively being explored and investments are being made to make use of the huge gas fields located in the south. It has many metallic and nonmetallic mines currently being explored. Iran is continuously working on its transportation system. It has become clear that the importance of road based transportation is as much as transportation by air and sea. Iran's road, especially those connecting east to the west have become a vital vein in global transportation system.

Upon the ratification of the Stock Exchange Act in 1967, the Tehran Stock Exchange was formed as a small center for trading corporate and government bonds. During the 1970s, Iran's economy was experiencing a booming period as a result of high oil prices (Salehi, 2009). This led to the release of suppressed demands for equities. In response to this high demand, the government would actively grant shares of companies that would either belong to the government or were privately owned by families. This supply and demand cycle caused the market to reach its peak exactly before the 1979 revolution (Mousavi et al., 2013).

After the Islamic revolution, the economic principles were changed drastically. Interest-based activities were banned, and many firms and organizations were nationalized. Iran got into an eight year war with its neighboring country, Iraq, and many resources were shifted towards this war. All this, hand in hand, caused the Tehran Stock Exchange to come into a stand still.

During the reconstruction period, attention was given again towards the privatization of industries. In 1989, the government decided to privatize many of its state-owned industries (Salehi and Sepehri, 2013). This affected the TSE's operation as one of the main tools to achieve this goal. According to article 44 of the
Islamic Republic constitution, the government should only assume the role of a policy maker rather than the direct owning and managing of its firms and industries. In compliance with this constitutional article, many state-owned firms have recently been privatized using the Tehran Stock Exchange and many more are expected to follow suit. Different industries ranging from automotive, telecommunications, agriculture, banking and insurance, petrochemicals, mining and steel are listed in TSE (Mousavi et al., 2013).

\section{Review of the Literature}

This debate over the relation between financial constraints and investment-cash flow sensitivity extends to the international context as well. Hoshi, Kashyap, and Scharfstein (1991), Schaller (1993), and Shin and Park (1998) present evidence from Japanese, Canadian, and Korean data, respectively, showing that the sensitivity is higher for more constrained firms.

Fazzari, Hubbard, and Petersen (1988) find a positive sensitivity of investment to cash flow, even after controlling for investment demand measured by Tobin's q. They posit that financially constrained firms, defined by low-dividend-paying firms, demonstrate relatively high ICF sensitivities compared to unconstrained firms, and argue that when there are financial constraints, external financing is not always available and the investment is financed by internal funds.

Love (2001) uses an Euler equation approach and confirms the FHP hypothesis by showing that firms in less developed countries show a greater sensitivity of investment to cash stock.

Allayannis and Mozumdar (2001) shown that negative cash flow observations may have a serious distortionary impact on estimated investment-cash flow sensitivities. The intuition is that when firms are in sufficiently bad shape (incurring cash losses), investments are down to their lowest possible levels and cannot be cut any further. In such situations, therefore, investmentcash flow sensitivity is extremely low. Including such negative cash flow observations in the sample reduces the estimated sensitivity for the entire sample.

Houston and James (2001) find that the estimated sensitivity is higher for firms that are closely tied to a single bank than firms that have relationships with several banks. Using detailed information on the debt structure of 250 publicly traded US firms, they also find that investment cash flow sensitivity increases as a firm's reliance on bank financing increases. In their sample, bank-dependent firms tend to hold larger stocks of liquid assets and have lower dividend payout rates. However, for most levels of investment spending, bank dependent firms appear to be slightly less cash-flow constrained than firms with access to public debt markets only. Their explanation for this observation is that close banking relationships help to reduce information asymmetries and thereby improve the capital allocation process. 
Allayannis and Mozumdar (2001) provide supporting empirical evidence, showing that firms hedge with derivatives to reduce the impact of financial constraints on investment-cash flow sensitivity.

Firth et al., (2012) investigate the relation between the internally generated cash flows and fixed asset investments of Chinese firms and find that it is U-shaped. The results reveal that government controlled listed firms have greater investment-cash flow sensitivities than do privately controlled listed companies, especially on the left-hand side of the U-shaped curve where cash flow is negative. However, the difference in sensitivities appears only among firms that possess few profitable investment opportunities. They attribute this finding to the government having multiple socio-economic objectives, which leads to increased capital expenditures by the firms it controls when internal funds are abundant and when internal funds are negative.

Cleary, Pavel, and Raith (2007) found that there is a nonlinear U-shaped relationship between a firm,s investment and its internal cash flow. They show empirically that if internal funds are negative, a further decrease in internal funds might make it optimal for the firm and lender to increase borrowing to such a degree that there can be a negative correlation between investment and cash flow. Lyandres (2007) and Hovakimian (2009) support the nonlinearity of the relationship by both theoretical model and empirical evidence. However, Chen and Chen (2012) find that sensitivity has declined and completely disappeared among the US firms, even during the 2007-2009 credit crunches. The earlier papers in the area, using US data from the seventies and early eighties, have reported sensitivities in the 0.4-0.7 range, studies employing data from the late eighties and nineties have found sensitivities in the 0.1-0.2 range, and most recent studies have documented estimates below 0.1 .

Huang (2002) examines the relation between financial constraints and cash flow-investment sensitivity. Using dividend payout ratio as a priori classification scheme, the results showed that the relationship is nonlinear.

Allayannis and Mozumdar (2004) demonstrate that the negative relationship between financial constraints and cash flow sensitivity is mostly driven by the increase in observations with negative cash flow over time.

Almeida and Campello (2009) provide alternative explanation and suggest that costly outside financing plays a differential role between financially constrained and unconstrained firms. For unconstrained firms, internal cash flow and outside financing are substitutes. Thus, unconstrained firms increase ICF sensitivity when reducing costly outside financing. However, constrained firms usually have a low level of cash flow, and they can make investments only when they have enough cash flow and outside financing at the same time.

Almeida and Campello (2007) examine the interaction term between cash flow and asset tangibility of a firm. They find that asset tangibility increases the sensitivity of financially constrained firms, while asset tangibility does not have a significant impact on the sensitivity of unconstrained firms. Agca and Mozumdar (2008) measure the interaction between cash flow and the factors that are associated with capital market imperfections. They find that cash flow sensitivity decreases with increasing fund flows, institutional ownership, analyst following, anti-takeover amendments and with the existence of a bond rating. This implies a negative relationship between a firm's information asymmetry and its sensitivity.

Islam and Mozumdar (2007) use international data from 31 countries and show that the sensitivity of investment to cash flow decreases with financial development. The latter study however examines only early and a relatively short period between 1987 and 1997, and uses only two aggregate measures of a country's financial development.

Ascioglu et al. (2007) examine the effect of information asymmetry on cash flow-investment sensitivity. They showed that scaled investment expenditures are on average lower and the investment-cash flow sensitivity is greater when the probability of informed trading is high.

Ezzedine and Salma (2007) examine cash flowinvestment sensitivity and cash flow-cash sensitivity in Tunisian firms. They showed that constrained firms have higher cash flow-investment sensitivity, while no significant difference was found between constrained and unconstrained firms in terms of cash flow-cash sensitivity. They attributed the results to the fact that firms with severe financial constraints are exposed to high costs of external finance, which induce the transaction motive of cash detentions, implying to use cash reserves to face current expenditures, in opposition with precaution motive to save cash out of cash flow to be able to finance future investments.

Arabsalehi and Ashrafi (2011) examine the relationship between financial constraints and investment-cash flow sensitivity. They found that cash reserves have a positive effect on the investment-cash flow sensitivity of firms. Shoorvarzy et al. (2012) examine the effect of accounting information quality on cash flow-investment sensitivity of listed companies in TSE. The results suggested a significant negative relationship between these two variables. In other words, improved accounting information decreases cash flow-investment sensitivity. In addition, they found that investment constraint cancels the effect of accounting information quality on cash flow-investment sensitivity.

Chen and Chen (2012) however, find that ICF sensitivity is almost zero during this period and conclude that the sensitivity cannot be a good measure of financial constraints.

Almeida et al. (2004) show that financially constrained firms tends to hold cash when they have increasing cash flow. In other words, constrained firms have higher cash flow-investment sensitivity than unconstrained firms.

Willenborg and McKeown (2001) examine the relationship between going concern audit opinion and 
certain financial ratios. Using Pearson correlation coefficient and regression analysis, they found that net income to total assets and inventory turnover ratio were the most important variables in the model.

Gómez-Guillamón (2003) evaluates the usefulness of audit report in investment and financing decisions. He argues that the usefulness of auditor's report is sometimes called into question and thus users when making decisions criticize the validity of its information content. The results of a survey among the users of audit reports showed that the users consider the information provided in the auditor's opinion as useful and important when making decisions.

Kashanipour and Naghinejad (2009) conclude that there is no significant difference between constrained and unconstrained firms in cash flow-investment sensitivity. They argued that investment-cash flow sensitivity is a more appropriate determinant of financial constraints.

Bartov et al. (2000) examine the association between discretionary accruals and audit qualification. They found that firms with unqualified audit reports have higher debt ratio than firms with qualified reports.

\section{Hypotheses development}

Information asymmetry and agency dilemma are considered as important factors that affect the resource allocation process and financial constraints of businesses. Financial constraints are a widespread key concern for firms, hindering their ability to carry out their optimal investment and growth trajectories (Carreira and Silva, (2010). Financial constraints occur when there is a gap between the costs of internal and external financing (Arabsalehi and Ashrafi, 2011). As Modigliani and Miller (1958) argued, market imperfections, which are the result of undeveloped legal and financial systems, lead to a wedge between the cost of internal and external funds. Thus, the business is faced with an added value in external financing, which constrains the financial decisions of the business and limits their ability in financing investment projects. Under these conditions, businesses are forced to rely on their internal sources (cash reserves from operations, operating revenues, etc.) instead of external financing (debt and share issuance), which in turn hinder the growth of businesses.

Auditing financial statements is one way to reduce information asymmetry and agency problems. Based on the signaling theory, financial statements and audit reports contain important information and signals for investors and other groups. Audit report reveals the quality of information provided in financial statements. There are two theories regarding the effect of audit report, especially modified audit opinion, on the financial constraints of businesses. The first theory is the theory of information asymmetry. Audit report includes useful information regarding the quality of annual reports. Thus, receiving modified audit opinion is a sign of reduced information quality and increased information asymmetry between internal and external users, which in turn increases the financial constraint of businesses. The second one is referred to as the Soft Budget Constraint theory. According to this theory, in firms with strong political links which are supported by the government, unqualified reports are supported by the government, and government interference facilitates the financing of the firm and reduces its financial constraint (Lin et al., 2011).

Given the theoretical background and the review of the literature as well as the aims of this study, the first hypothesis postulated as following:

Hypothesis 1: Receiving modified reports affects cash flow-investment sensitivity.

Information asymmetry implies that market participants do not have equal access to information. For instance, internal users may have more detailed information regarding the strategic decisions of the company that they do not share with external investors (Kadapakkam et al., 1998). Information asymmetry leads to risk and moral hazard for external fund providers. Creditors consider a compensation for financing in return for the risks they take; for instance, they raise interest rates on what the company has borrowed or they buy its stocks at a lower price. This is referred to as underpricing. Thus, information asymmetry can lead companies toward underinvestment (Kashanipour \& Naghinejad, 2009).

Agency problems are due to separation of ownership and control. The interests of managers and shareholders very consistent and managers tend to maximize firm size. A large body of research has shown that managers of large corporates have higher financial and non-financial interests and benefits than managers of small corporates. Therefore, the goal of the management may be to maximize firm size instead of firm value. Agency problems can lead to overinvestment. Agency problems can go beyond manager-investor relationship and involve creditors as well. To create value for shareholders, managers may have a tendency to invest in riskier projects than those agreed with creditors. These projects lead to transfer of value from bondholders to investors, for the latter would not pay any of the gains from riskier ventures to bondholders, while bondholders bear part of the risk of failure. So bondholders would have an incentive to increase the cost of capital though interest rates, bond indentures, or other legal devices (Kashanipour \& Naghinejad, 2009).

So, the second hypothesis is postulated as following:

Hypothesis 2: The type of report affects cash flowinvestment sensitivity.

Sub-hypothesis 2-1: Receiving unqualified report with explanatory paragraphs affects cash flow-investment sensitivity. 
Sub-hypothesis 2-2: Receiving qualified report affects cash flow-investment sensitivity.

Sub-hypothesis 2-3: Receiving disclaimed opinion or adverse opinion affects cash flow-investment sensitivity.

\section{Methodology}

\section{a. Population and Sample}

The population of the present research consists of all listed companies in TSE. No sampling is used in this study; instead, firms that met the following conditions are examined:

- Firms' financial year must end at the end of Iranian calendar;

- Firms must not have no changes the financial year (not converting fiscal year);
- During the studied period (2006-2010), the stocks of these firms must have been traded at least once every three months;

- Firms must have data available on the selected variables.

Out of 478 listed companies, only 123 companies meet the above conditions.

\section{b. Procedure}

This research examines the effect of audit report on cash flow-investment sensitivity in TSE-listed firms. Thus, it is an applied research with a quasi-experimental and ex post facto design. Since the researcher does not manipulate the data, the research has high external validity (Namazi, 2000). The data was collected from the financial statements of the firms as well as the software provided by TSE.

Table 1. A description of the variables

\begin{tabular}{lll}
\hline Description & Proxy & Variable \\
\hline Investment expenditure, measured as annual purchases of fixed assets & INVEST & Investment \\
Net cash flow generated from operating activities & OCF & Operating Cash Flow \\
Equals 1 if last year's audit report is modified, and 0 otherwise & MAO & Modified Audit Report \\
Equals 1 for firms receiving this report last year, and 0 otherwise & UQUA & Unqualified Audit Report with \\
& EXPLAN & Explanatory Paragraphs \\
Equals 1 if last year's audit report is qualified, and 0 otherwise & QUAO & Qualified Opinion \\
Equals 1 for firms receiving this report last year, and 0 otherwise & DISC ADVS & Disclaimed Opinion or Adverse \\
& & Opinion \\
Equals 1 for non-government agencies, and 0 otherwise & PRVI & Ownership \\
Annual revenue growth rate & GROWTH & Growth Opportunities \\
Natural logarithm of total assets & SIZE & Firm Size \\
\hline
\end{tabular}

Multivariate regression and synthetic data are used for data analysis. Due to using synthetic data, before running the main regression model, one of the fixed, common, or random effects models is selected using Chow test and Hausman test and then the main regression model is accordingly estimated. Calculations and data extraction are done in Excel and data analysis and hypothesis testing are done in EViews. Finally, the research hypotheses are tested through regression analysis, F-statistic, and coefficient of determination $\left(\mathrm{R}^{\wedge} 2\right)$ at 95\% confidence interval.

Regression model (1) is used to test the first hypothesis and regression model (2) is used to test the second hypothesis as well as its sub-hypotheses.

\section{Regression model (1)}

$\mathrm{INVEST}_{\text {it }}=\alpha+\beta_{1} \mathrm{OCF}_{\text {it }}+\beta_{2} \mathrm{MAO}_{\text {it- } 1}+\beta_{3} \mathrm{MAO}_{\text {it- } 1} \times$ $\mathrm{OCF}_{\text {it }}+\beta_{4} \mathrm{PRIV}_{\text {it }}+\beta_{5} \mathrm{PRIV}_{\text {it }} \times \mathrm{OCF}_{\text {it }}+\beta_{6} \mathrm{GROWTH}_{\text {it }}$ $+\beta_{7} \mathrm{SIZE}_{i \mathrm{i}}+\varepsilon$

\section{Regression model (2)}

$\mathrm{INVEST}_{\downarrow}$ it $=\alpha+\beta_{\downarrow}$ 1OCF $_{\downarrow}$ it $+\beta_{\downarrow} 2$ UQAOEXPLAN $_{\downarrow}$ (it-1) $+\beta_{\downarrow} 3 \mathrm{QUAO}_{\downarrow}($ it- 1$)+\beta_{\downarrow} 4 \mathrm{DISC}^{\mathrm{ADVS}} \mathrm{DV}_{\downarrow}($ it- 1$)+\beta_{\downarrow} 5 \mathrm{UQAO}$ $\operatorname{EXPLAN}_{\downarrow}($ it- 1$) \times \mathrm{OCF}_{\downarrow}$ it $+\beta_{\downarrow} 6 \mathrm{QUAO}_{\downarrow}$ (it- 1$)$

The variables incorporated in the models are summarized and described in Table 1. 
Table 2. Descriptive statistics of the research variables

\begin{tabular}{llllll}
\hline SD & Max & Min & Mean & Observations & Variable \\
\hline 107298.64 & 1087615.00 & 1.00 & 47334.98 & 615 & INVEST \\
476165.76 & 4241709.00 & -2413332.00 & 148835.15 & 615 & OCF \\
0.47062 & 1.00 & 0.00 & 0.6699 & 615 & MAO \\
400474.71 & 3519782.00 & -2413332.00 & 98220.52 & 615 & MAO $\times$ OCF \\
0.49388 & 1.00 & 0.00 & 0.4195 & 615 & PRIV \\
79654.21 & 711748.00 & -805579.00 & 22386.46 & 615 & PRIV $\times$ OCF \\
0.34450 & 1.86 & -0.81 & 0.1706 & 615 & GROWTH \\
1.297 & 9.82 & 16.76 & 13.185 & 615 & SIZE \\
0.4097 & 1.00 & 0.00 & 0.2130 & 615 & UQAO EXPLAN \\
0.4706 & 1.00 & 0.00 & 0.6699 & 615 & QUAO \\
0.00 & 0.00 & 0.00 & 0.00 & 615 & DISC ADVS \\
92588.35 & 1221993 & -805579.0 & 21096.24 & 615 & UQAO EXPLAN $\times$ OCF \\
400474.7 & 3519782.0 & -2413332.0 & 98220.52 & 615 & QUAO $\times$ OCF \\
0.00 & 0.00 & 0.00 & 0.00 & 615 & DISC ADVS $\times$ OCF \\
\hline
\end{tabular}

\section{Findings}

The descriptive statistics of the variables are provided in Table 2. As can be seen, OCF has the highest standard deviation, while DISC ADVS and DISC ADVS $\times$ OCF has the lowest standard deviation. This indicates that OCF has the highest level of dispersion. Since in the sample there was no instance of a firm with disclaimed or adverse opinion, the value of DISC ADVS was zeroed and thus the product of this variable multiplied by $\mathrm{OCF}$ is zero. Moreover, the highest mean belongs to OCF.

Table 3. The results of Levin-Lin-Chu test

\begin{tabular}{lll}
\hline Sig. & Test Statistic & Variable \\
\hline 0.0000 & -51.2986 & INVEST \\
0.0000 & -50.1856 & OCF \\
0.0000 & -5.45813 & MAO \\
0.0000 & -33.9682 & MAO $\times$ OCF \\
0.0000 & -3.73951 & PRIV \\
0.0000 & -24.4207 & PRIV $\times$ OCF \\
0.0000 & -45.7197 & GROWTH \\
0.0000 & -33.6593 & SIZE \\
0.0000 & -6.16598 & UQAO EXPLAN \\
0.0000 & -5.45813 & QUAO \\
0.0000 & -14.4821 & UQAO EXPLAN $\times$ OCF \\
0.0000 & -33.9682 & QUAO $\times$ OCF \\
- & - & DISC ADVS \\
- & - & DISC ADVS $\times$ OCF \\
\hline
\end{tabular}

Before testing the hypotheses with regression model and synthetic data, unit root test must be applied for all the variables to examine whether or not they are stationary. If the variables are non-stationary, estimation of econometric models with these variables creates spurious regression. The results of unit root test are presented in Table 3. Significance levels below 5\% indicate the stationarity of the data.

The results of Chow and Hausman tests for selecting the most appropriate model are provided in Table 4. First, Chow test is applied to choose between fixed and mixed models. If the fixed effects model was preferred, it must be tested against random effects model using Hausman test.

Considering the above table, the random effects model is selected for all the hypotheses.

\section{a. The First Hypothesis}

The results of testing the first hypothesis are provided in Table 5. The coefficient of modified report (MAO) is less than 5\%, suggesting its significance. In other words, modified audit report significantly affects cash flowinvestment sensitivity. The negative coefficient indicates the negative relationship between these variables. However, the coefficient of OCF is 0.3985 , which is greater than the 5\% significance level. Therefore, there is no significant relationship between operating cash flow and investment. Although the relationship is not strong, the positive coefficient indicates a positive relationship between these variables, indicating that investment increases with cash flow. 
Table 4. The results of Chow and Hausman test

\begin{tabular}{|c|c|c|c|c|}
\hline Model & Sig. & Test Statistic & Test & Hypothesis \\
\hline \multirow[t]{2}{*}{ Random effects } & 0.0054 & 3.704960 & Chow test & Hypothesis 1 \\
\hline & 1.0000 & 0.0000 & Hausman test & \\
\hline \multirow[t]{2}{*}{ Random effects } & 0.0039 & 3.895968 & Chow test & Hypothesis 2-1 \\
\hline & 1.0000 & 0.0000 & Hausman test & \\
\hline \multirow[t]{2}{*}{ Random effects } & 0.0056 & 3.88939 & Chow test & Hypothesis 2-2 \\
\hline & 1.0000 & 0.0000 & Hausman test & \\
\hline
\end{tabular}

Table 5. Results of the estimation of the first hypothesis

\begin{tabular}{|c|c|c|c|c|}
\hline Sig. & $t$-statistic & Standard Error & Coefficient & Variable \\
\hline 0.3958 & 0.849686 & $2.22 \mathrm{E}-07$ & $1.88 \mathrm{E}-07$ & $\mathrm{OCF}$ \\
\hline 0.0000 & -4.561083 & 0.123625 & -0.563857 & MAO \\
\hline 0.3155 & 1.004546 & $2.21 \mathrm{E}-07$ & $2.22 \mathrm{E}-07$ & $\mathrm{MAO} \times \mathrm{OCF}$ \\
\hline 0.9280 & 0.090350 & 0.185034 & 0.016718 & PRIV \\
\hline 0.2837 & 1.073004 & $7.45 \mathrm{E}-07$ & $7.99 \mathrm{E}-07$ & $\mathrm{PRIV} \times \mathrm{OCF}$ \\
\hline 0.0574 & -1.903918 & 0.130389 & -0.248249 & GROWTH \\
\hline 0.0000 & 12.36958 & 0.071650 & 0.886280 & SIZE \\
\hline 0.0349 & -2.113883 & 0.972710 & -2.056195 & $\mathrm{C}$ \\
\hline \multicolumn{2}{|c|}{ Significance: 0.0000} & \multicolumn{3}{|c|}{ F-statistic: 33.53227} \\
\hline \multicolumn{2}{|c|}{ Durbin-Watson statistic: 1.607475} & Adjusted $R^{2}: 0.27$ & & $R^{2}: 0.278863$ \\
\hline
\end{tabular}

According to the data in Table 5, the first hypothesis is accepted, i.e. receiving modified audit report affects cash flow-investment sensitivity. Of course, the product of $\mathrm{MAO} \times \mathrm{OCF}$ is not significant. Among the control variables, there is a significant relationship only between firm size and investment. They value of F-statistic and its significance level is 33.53 and 0.000 respectively, indicating that the estimated regression model is generally significant. The value of $R^{2}$ is 0.27 , suggesting that $27 \%$ of the variance in the dependent variable can be explained by the independent and control variables. In addition, the value of Durbin-Watson statistic is within the 1.5-2.5 range (1.60), which indicates the lack of auto-correlation.

\section{b. The Second Hypothesis}

The results of testing sub-hypothesis 2-1 are presented in Table 6.

As the above table shows, the $p$-value of OCF is less than $5 \%$ and significant. Its positive coefficient suggests that there is a significant positive relationship between OCF and investment. Also the $p$-value of
UQAO EXPLAN indicates its significance. Therefore, sub-hypothesis 2-1 is accepted, i.e. receiving unqualified report with explanatory paragraphs affects cash flowinvestment sensitivity. Size is the only control variable that is significantly associated with investment. The value of $R^{2}$ is 0.26 , implying that $26 \%$ of the variance in the dependent variable can be explained by the variables incorporated in the model. The value of Durbin-Watson statistic is 1.58, suggesting the lack of auto-correlation. In addition, the significance level of F-statistic (0.0000) indicates that the overall regression model is significant.

As shown in Table 7, the $p$-value of OCF is greater than $5 \%$ and thus not significant. Meanwhile OCF is positively associated with investment, though the relationship is weak. Moreover, the $p$-value of QUAO is less than $5 \%$, indicating the significance of this variable. Therefore, the sub-hypothesis is accepted, i.e. receiving qualified report affects cash flow-investment sensitivity. There is also a significant relationship between the control variable of SIZE and investment. The value of $R^{2}$ is 0.27 , suggesting that $27 \%$ of the variance in the dependent variable can be explained by the independent and control variables. The value of Durbin-Watson statistic is 1.61 that is within the range $1.5-2.5$; therefore, there 
Table 6. Estimation of sub-hypothesis 2-1

\begin{tabular}{lllll}
\hline Sig. & $\boldsymbol{t}$-statistic & Standard Error & Coefficient & Variable \\
\hline 0.0035 & 2.934579 & $1.35 \mathrm{E}-07$ & $3.95 \mathrm{E}-07$ & OCF \\
0.0007 & 3.390020 & 0.144336 & 0.489303 & UQAO EXPLAN \\
0.1676 & -1.381519 & $6.01 \mathrm{E}-07$ & $-8.31 \mathrm{E}-07$ & UQAO EXPLAN $\times$ \\
& & & & OCF \\
0.7743 & -0.286907 & 0.188944 & -0.054210 & PRIV \\
0.1371 & 1.488567 & $8.07 \mathrm{E}-07$ & $1.20 \mathrm{E}-06$ & PRIV $\times$ OCF \\
0.1262 & -1.531258 & 0.083579 & -0.127981 & GROWTH \\
0.0000 & 11.90628 & 0.072833 & 0.867172 & SIZE \\
0.0219 & -2.298355 & 0.989716 & -2.274719 & C \\
\hline Significance: 0.0000 & & & F-statistic: 30.885657 & \\
Durbin-Watson statistic: 1.581516 & & Adjusted $R^{2}: 0.253945$ & $R^{2}: 0.262451$ \\
\hline
\end{tabular}

Table 7. Estimation of sub-hypothesis 2-2

\begin{tabular}{lllll}
\hline Sig. & t-statistic & Standard Error & Coefficient & Variable \\
\hline 0.4037 & 0.835595 & $2.22 \mathrm{E}-07$ & $1.86 \mathrm{E}-07$ & OCF \\
0.0000 & -4.638561 & 0.123885 & -0.574646 & QUAO \\
0.3063 & 1.023923 & $2.21 \mathrm{E}-07$ & $2.27 \mathrm{E}-07$ & QUAO $\times$ OCF \\
0.9032 & 0.121721 & 0.185203 & 0.022543 & PRIV \\
0.3226 & 0.989939 & $7.43 \mathrm{E}-07$ & $7.36 \mathrm{E}-07$ & PRIV $\times$ OCF \\
0.1241 & -1.539976 & 0.083001 & -0.127820 & GROWTH \\
0.0000 & 12.39379 & 0.071700 & 0.888634 & SIZE \\
0.0314 & -2.157339 & 0.972910 & -2.098896 & C \\
\hline Significance: 0.0000 & & & F-statistic: 33.34966 & \\
Durbin-Watson statistic: 1.610307 & & Adjusted $R^{2}: 0.269437$ & $R^{2}: 0.277766$ \\
\hline
\end{tabular}

is no auto-correlation in the model. The significance of F-statistic (0.0000) suggests the significance of the overall regression model.

As for the third sub-hypothesis, this hypothesis was not tested since the sample firms had not received any disclaimed or adverse opinion.

\section{Conclusion}

The purpose of the present study was to examine whether the type of audit report has any significant effect on cash flow-investment sensitivity. The first hypothesis addressed the effect of receiving modified audit report on cash flow-investment sensitivity. The results of estimating the regression model suggested that there is a significant negative relationship between these variables.
The second hypothesis addressed the effect of different types of audit reports (i.e. unqualified audit report with explanatory paragraphs, qualified audit report, and disclaimed or adverse opinion) on cash flow-investment sensitivity, and these effects were tested in the form of three sub-hypotheses. The results of indicated a significant positive relationship between receiving unqualified audit report with explanatory paragraphs and cash flowinvestment sensitivity. A significant negative relationship was observed between receiving qualified audit report and cash flow-investment sensitivity. Since the studied firms had not received any disclaimed or adverse opinion, the third sub-hypothesis was not tested. In general, the results of testing these hypotheses support each other and there is no inconsistency between them. Among the control variables, firm size was always associated with 
investment. This indicates that larger firms have higher levels of investment that is logical.

The root for the significant effect of various types of audit report on cash flow-investment sensitivity can be found in the link between audit report and the quality of financial information. Audit report serves as a certificate for the quality of financial statements. According to the signaling theory, financial statements and audit reports contain important information and signals for investors and other users. Audit report reveals the quality of information provided in financial statements and this influences the future investments and financing of the firm. For instance, in the theory of asymmetric information, it is argued that modified audit report contains important indications about the quality of annual reports; thus, receiving such reports suggests the information asymmetry between internal and external users, which in turn increases the financial constraints of the firm. One strategy for reducing financial constraint is to increase transparency and improve the quality of financial information, which is feasible only through auditing. The authors believe that the outcomes of the study may give great strength to the Iranian capital market as well other developing countries which have the same Iranian conditions. In nutshell, the audit reports have great effect to firm financing. So, the firms may get unqualified audit reports may leads great financial constrains in the future.

\section{Further to the study}

According to the results of the current study, the following suggested for future studies:

1. Employing new variables to cash flow sensitivity.

2. Study on the effect of audit report on cash flow sensitivity in unprofitable companies.

3. The effect of other financing methods on cash flow sensitivity.

\section{References}

Abdel-Khalik, R. (1979). Empirical Research in Accounting: A Methodological Viewpoint. American Accounting Association.

Agca, S. \& Mozumdar, A. (2008). The impact of capital market imperfections on investment-cash flow sensitivity. Journal of Banking and Finance, 32, 207-216, http://dx.doi. org/10.2139\%2Fssrn.686812

Allayannis, G. \& Mozumdar, A. (2001). The Investment-Cash Flow Sensitivity Puzzle: Can Negative Cash Flow Observations Explain It? Working Paper, Virginia Tech.

Allayannis, G. \& Mozumdar, A. (2004). The impact of negative cash flow and influential observations on investment-cash flow sensitivity estimates. Journal of Banking and Finance, 28, 901-930, http://dx.doi.org/10.1016\%2FS0378-4266\%2803\%2900114-6

Almeida, H. \& Campello, M. (2009). Financing frictions and the substitution between internal and external funds. Journal of Financial and Quantitative Analysis, 45(3), 589-622, http:// dx.doi.org/10.1017\%2FS0022109010000177
Almeida, H., Campello, M. \& Weisbach, M. S. (2004). The cash flow sensitivity of cash. The Journal of Finance, 59, 1777-1804, http://dx.doi.org/10.1111\%2Fj.1540-6261.2004.00679.x

Almeida, H. \& Campello, M. (2007). Financial constraints, asset tangibility, and corporate investment. Review of Financial Studies, 5, 1429-1460, http://dx.doi.org/10.1093\%2Frfs\%2Fhhm019

Arabsalehi, M. \& Ashrafi, M. (2011). The role of cash reserves in determining cash flow-investment sensitivity in TSE-listed firms. Iranian Journal of Accounting Research, 3, 75-94.

Arslan, O., Florackis, C. \& Ozkan, A. (2006). The role of cash holdings in reducing investment-cash flow sensitivity: Evidence from a financial crisis period in an emerging market. Emerging Markets Review, 7, 320-338, http://dx.doi.org/10.1016\%2Fj. ememar.2006.09.003

Ascioglu, A., Hedge, S. P. \& McDermott, J. B. (2007). Information asymmetry and investment-cash flow sensitivity. Journal of Banking \& Finance, 32, 1036-1048, http://dx.doi. org/10.1016\%2Fj.jbankfin.2007.09.018

Bartov, E., Gul, F. A., \& Tsui, J. S. L. (2000). Discretionaryaccruals models and audit qualifications. Journal of Accounting \& Economics, 30, 421-452, http://dx.doi.org/10.1016\%2 FS0165-4101\%2801\%2900015-5

Barzegar B. \& Salehi, M. (2008). Re-emerging of Agency Problem: Evidences from Practicing Non-Audit Services by Independent Auditors. Journal of Audit Practice, 5(2), 55-66.

Beatty, A., Liao, S. \& Weber, J. (2010). The effect of private information and monitoring on the role of accounting quality in investment decisions. Contemporary Accounting Research, 27, 17-47.

Bekaert, G., Harvey, C., Lundblad, C. \& Siegel, S. (2011). What segments equity markets. Review of Financial Studies, 24(12), 3841-3890, http://dx.doi.org/10.1093\%2Frfs\%2Fhhr082

Bottom, W.P., Holloway, J., Miller, G.J., \& Mislin, A.M. (2006). Pathways to Cooperation: Negotiation and Social Exchange between Principal and Agent. Administrative Science Quarterly, 51(1), 29-58.

Campello, M., Graham, J. \& Harvey, C. (2010). The real effects of financial constraints: evidence from a financial crisis. Journal of Financial Economics, 97, 470-487, http://dx.doi. org/10.1016\%2Fj.jfineco.2010.02.009

Carreira, C. \& Silva, F. (2010). No deep pockets: some stylized empirical results on firms' financial constraints. Journal of Economic Surveys, 24(4), 731-753, http://dx.doi.org/10.1111/ j.1467-6419.2009.00619.x

Chen, H. \& Chen, S. (2012). Investment-cash flow sensitivity cannot be a good measure of financial constraints: Evidence from time series. Journal of Financial Economics, 103, 393-410, http:// dx.doi.org/10.1016\%2Fj.jfineco.2011.08.009

Cleary, S., Pavel, P. \& Raith, M. (2007). The U-shaped investment curve: theory and evidence. Journal of Financial and Quantitative Analysis, 42, 1-39, http://dx.doi.org/10.1017\%2 FS0022109000002179

Ezzedine, A. \& Salma, B. (2007). Investment-cash flow sensitivity versus cash-cash flow sensitivity: What really matters for Tunisian firms. Working paper, University of Tunis, Tunis.

Fan, J.P.H. \& Wong, T.J. (2005). Do external auditors perform a corporate governance role in emerging markets? Evidence from East Asia. Journal of Accounting Research, 43 (1), 35-72, http:// dx.doi.org/10.1111\%2Fj.1475-679x.2004.00162.x

Firth, M., Malatesta, P.H., Xin, Q. \& Xu, L. (2012). Corporate investment, government control, and financing channels: Evidence from China's Listed Companies. Journal of Corporate Finance, 18, 433-450, http://dx.doi.org/10.1016/j.jcorpfin.2012.01.004

Gómez-Guillamón, A. D. (2003). The usefulness of the audit report in investment and financing decisions. Managerial 
Auditing Journal, 18, 549-559, http://dx.doi.org/10.1108\% 2F02686900310482687

Guariglia, A., Liu, X. \& Song, L. (2011). Internal finance and growth: microeconometric evidence on Chinese firms. J. Dev. Econ., 96, 79-94, http://dx.doi.org/10.1016\%2Fj.jdeveco.2010.07.003

Hoshi, T., Kashyap, A. \& Scharfstein, D. (1991). Corporate Structure Liquidity and Investment: Evidence from Japanese Panel Data. Quarterly Journal of Economics, 106, 33-60.

Houston, J.F., James, C. M. (2001). Do Relationships Have Limits? Banking Relationships, Financial Constraints, and Investment, Journal of Business, 74, (3), 347-373, http://dx.doi. org $/ 10.1086 \% 2 \mathrm{~F} 321930$

Hovakimian, G. (2009). Determinants of investment cash flow sensitivity, Financial Management, 38,161-183, http://dx.doi. org/10.1111\%2Fj.1755-053X.2009.01032.x

Huang, Z. (2002). Financial constraints and investment-cash flow sensitivity. Paper presented at EFA 2002 Berlin Meetings. Available at: http://papers.ssrn.com/sol3/papers.cfm?abstract_ id $=301580$

Islam, S. \& Mozumdar, A. (2007). Financial development and the importance of internal cash: evidence from international data. Journal of Banking and Finance, 31, 641-658, http://dx.doi. org/10.1016\%2Fj.jbankfin.2006.06.009

Kadapakkam, P. R., Kumar, P. C. \& Riddick, L. A. (1998). The impact of cash flows and firm size on investment: The international evidence. Journal of Banking and Finance, 22, 293-320, http://dx.doi.org/10.1016\%2FS0378-4266\%2897\%2900059-9

Kashanipour, M. \& Naghinejad, B. (2009). The effect of financial constraints on cash-cash flow sensitivity. Iranian Journal of Accounting Research, 2, 72-92.

Kassim, H. \& Menon, A. (2003). The principal-agent approach and the study of the European Union: promise unfulfilled? Journal of European Public Policy, 10(1), 121-139, http://dx.doi.org/10. 1080/1350176032000046976

Li, H., Meng, L., Wang, Q. \& Zhou, L.A., (2008). Political connections, financing and firm performance: evidence from Chinese private firms. Journal of Development Economics, 87, 283-299, http://dx.doi.org/10.1016\%2Fj.jdeveco.2007.03.001

Lin, H. \& Huang, C. (2011). Exploring agency problems in corporate governance from the perspective of economic ethics of the capitalist market, African Journal of Business Management, 5(28), 11442-11449. http://dx.doi.org/10.5897/AJBM11.586

Lin, Z., Jiang, Y. \& Xu, Y. (2011). Do modified audit opinions have economic consequences? Empirical evidence based on financial constraints, China Journal of Accounting Research, 4, 135-154, http://dx.doi.org/10.1016\%2Fj.cjar.2011.06.004

Love, I. (2001). Financial Development and Financing Constraints: International Evidence from the Structural Investment Model, Working Paper, Columbia University.

Lyandres, E. (2007). Costly external financing, investment timing, and investment-cash flow sensitivity. Journal of Corporate Finance, 13, 959-980, http://dx.doi.org/10.1016\%2Fj.jcorpfin.2007.07.001

Mashayekhi, B. \& Mashayekh S. (2008). Development of Accounting in Iran. International Journal of Accounting, 43, 66-86, http:// dx.doi.org/10.1016\%2Fj.intacc.2008.01.004

Meyer, J. R. \& Kuh, E. (1957). The Investment Decision, Cambridge: Harvard University Press.
Modigliani, F. \& Miller, M. H. (1958). The Cost of Capital, Corporation Finance and the Theory of Investment, American Economic Review, 48, 261-297.

Mousavi Shiri, M., Salehi, M., \& Bigmoradi, N. (2013). Internet Financial Reporting: Case of Iran, Journal of Distribution Science, 11(3), 49-62.

Myers, S.C. \& Majluf, N.S. (1984). Corporate financing and investment decisions when firms have information that investors do not. Journal of Financial Economics, 13, 187-221, http://dx.doi. org/10.1016\%2F0304-405X\%2884\%2990023-0

Salehi, M., Mansouri, A. \& Pirayesh, R. (2009). Firm Size and Audit Regulation and Fraud Detection: Empirical Evidence from Iran, ABAC Journal of Management, 29(1), 53-65.

Salehi, M. (2009). Tobin's Q Model and Cash Flows from Operating and Investing Activities Evaluating in Listed Companies in Iran, Zagreb International Review of Economic and Business, 7(2), 71-82.

Salehi, M. (2008). Evolution of Accounting and Auditing in Iran, Journal of Audit Practice, 5(4), 57-74.

Salehi, M., \& Abedini, B (2008). Iranian Angle: Worth of Audit Report, SCMS Journal of Indian Management, April-May, 82-90.

Salehi, M. \& Sepehri, F. (2013). A Study of Accruals Quality on Risk Assessment of Securities in Iran, Internal Auditing \& Risk Management, 8(1), 1-1380.

Schaller, H. (1993). Asymmetric Information, Liquidity Constraints, and Canadian Investment. Canadian Journal of Economics, 36 (3), 552-574, http://dx.doi.org/10.2307\%2F135887

Shoorvarzy, M. R., Mousavi Shiri, M., \& Kholousi, A. (2012). A study of impact of accounting quality on cash flow-investment sensitivity. World Applied Sciences Journal, 16, 141-146.

Wang C. \& Chen S. (2003). The Economics of Information, Taipei, National Open UP, p. 3.

Willenborg, M. \& McKeown, J. (2001). Going-concern initial public offerings. Journal of Accounting and Economics, 30, 279-313, http://dx.doi.org/10.1016\%2FS0165-4101\%2801\%2900014-3

Mahdi Salehi is an Assistant Professor of Accounting, Ferdowsi University of Mashhad, Iran. He has more than 8 years of academic experiences. So far, he has published more than 170 papers in international journals, his interests include: Auditing, Audit expectation gap, and financial distress prediction.

Ali Mohammadi is an Assistant Professor of Accounting, Zanjan Branch, Islamic Azad University, Zanjan, Iran. So far he published several papers in international as well national journals. His interests include: Financial reporting, cost accounting and auditing.

Parisa Taherzadeh Esfahani obtained her M.A in Accounting from the Accounting Department, Islamic Azad University, Zanjan Sciences \& Research Branch, Iran. 